\title{
Globale og lokale - men ikke for danske
}

\section{Af Jens-Peter Saul}

Danske virksomheders fordele på det globale eksp ortmarked er samtidig deres ulempe: Vi tilbyder i udstrakt grad løsninger, der er bæredygtige, effektive og resultatet af mange års udviklingsarbejde. Men andre lande kan sætte spørgsmålstegn ved, om det ikke er for dyrt eller besværligt at overføre dem. Det er derfor afgørende at kommunikere, at teknikkerne og de andre elementer ikke er skræddersyede til Danmark, men er så universelle, at de kan tilpasses lokale forhold.

\section{3,5 billioner dollars. Mindst!}

Så mange penge skal der flyttes frem mod 2030 for, at alverdens lande kan leve op til løfterne i klimaaftalen i Paris, ifølge blandt andre Det Internationale Energiagentur.

Og så har man ikke engang indkalkuleret de mange milliarder, som FN's mål om bæredygtig udvikling vil flytte, men som kan være endnu højere, og som ifølge blandt andre konsulentfirmaet KPMG bør få internationale koncerner til at revurdere deres kernestrategier.

Det er en fantastisk mulighed for danske virksomheder, fordi vi har arbejdet med bæredygtighed i årtier og allerede har godt gang i salget til udlandet: Eksporten af grøn energiteknologi havde tocifrede vækstrater i både 2013 og 2014.

Desuden har mange af os virksomheder allerede bæredygtighed inkorporeret i vores kernestrategier.

Men denne fordel kan i nogle tilfælde også paradoksalt nok blive vores ulempe og skabe barrierer, når vi i de kommende år i endnu højere grad vil forsøge at eksportere de løsninger, vi har udviklet.

Jeg vender tilbage til barriererne. Lad mig først se på, hvad det egentlig er, der er særlig relevant for danske virksomheder i Paris-aftalen og bæredygtighedsmålene.

\section{Danmark på det grønne spor}

Klimaaftalen skal holde den globale temperaturstigning under to grader i forhold til førindustrielt niveau og sigte efter at begrænse stigningen til 1,5 grader.

Det kræver blandt andet, at anvendelsen af ressourcerne optimeres - især at de i langt højere grad genanvendes - og det kræver en massiv omlægning af energisystemet; fra traditionelle fossile brændsler til især vedvarende kilder som sol og vind samt gennemgribende energieffekti- 
viseringer. Men det kræver også en tilpasning til de klimaændringer, der uvægerligt vil komme.

De krav er vi i Danmark ekstraordinært godt rustet til at honorere.

Danmark blev tvunget til at energieffektivisere, da de vestlige lande blev ramt af de to oliekriser i 1970'erne. Inden da bestod langt hovedparten af det danske energiforbrug af olieimport fra mere eller mindre ustabile regimer. Danmark gik nu i gang med at blive mere selvforsynende, både af hensyn til økonomien og forsyningssikkerheden - og efterhånden også miljøet - og et par årtier senere var vi godt i gang med at udskifte olie og kul med det mindre forurenende gas.

Vi havde fået gang i det, der blev til et eksporteventyr for vindmøller. Og vi var holdt op med at 'fyre for gråspurvene', som det hed dengang: Vi havde isoleret husene og var i det hele taget blevet gode til at genanvende overskudsenergi fra ét område til et andet. Ikke mindst i fjernvarmesystemet.

Danmark var med andre ord allerede i færd med at 'forgrønne' vores energisystem, da klimaspørgsmålet for alvor kom på den politiske dagsorden i det nye årtusinde.

\section{Klimainvesteringers merværdi}

Det var også i de første år af det nye årtusinde, at Danmark fik forsmag på det voldsommere vejr, som klimaændringerne fører med sig. Året før jeg kom til Rambøll oplevede København den hidtil mest ødelæggende oversvømmelse. På den julinat i 2011 var vandet få millime- ter fra at slukke nødgeneratorer på Rigshospitalet og Hvidovre Hospital, tusindvis af kældre blev oversvømmet, og bilisterne var strandet på motorvejen - nogle steder med vand op til taget.

Den samlede regning for de materielle skader var på mere end en milliard dollars.

Men skybruddet fremskyndede Københavns klimainitiativer. Kommunalbestyrelsen indså, at prisen for ikke at gøre noget langt fra er nul. Det er langt dyrere at lade skybrud og andre ekstreme vejrfænomener ramme end at udvikle en klimarobust by.

Samtidig kan investeringer i klimaprojekter have en betydelig merværdi på velfærd og livskvalitet - og ejendomspriser hvis byerne tør have en innovativ tilgang. I København forsøger man så vidt muligt at holde skybrudsvandet over jorden frem for at skulle udvide kloakkerne under jorden, og dermed transformeres grå stenbro og asfalt til blågrønne områder med rekreativ værdi.

Bare ét af projekterne - omdannelsen af Skt. Jørgens Sø til en strandpark - kan potentielt spare et tocifret millionbeløb i dollar i forhold til en traditionel løsning, hvor man nøjes med at udvide kapaciteten for underjordiske rør. Rambøll er med i dette projekt - og mange andre; i partnerskab med ikke kun kommuner og forsyningsselskaber, men også private virksomheder, foreninger og fonde som for eksempel Realdania.

København og virksomheder som Rambøll oplever stigende udenlandsk interesse for disse klimaløsninger. Men vi støder

Danmark var med andre ord allerede i færd med at 'forgrønne' vores energisystem, da klimaspørgsmålet for alvor kom på den politiske dagsorden i det nye årtusinde. 
Samtidig kan investeringer i klimaprojekter have en betydelig merværdi på velfærd og livskvalitet - og ejendomspriser - hvis byerne tør have en innovativ tilgang.

stadig ofte på den opfattelse, at de nordiske klimaløsninger, som vi forsøger at sælge, netop er: for nordiske. Eller endnu værre: for danske.

Der kan måske være forskelle i måden at drive politik på, med fordelingen mellem offentlig og privat ejendomsret, med at markedet ikke lige er klar til at springe fra en meget traditionel teknologi til en meget moderne - eller helt jordnært med at prisen for teknologien opleves som for høj i forhold til landets levestandard.

\section{New York}

En del amerikanere har for eksempel været skeptiske overfor, om løsningerne er for tilpasset Danmark, fordi der er en udbredt opfattelse af, at regering og kommunalbestyrelser hér bare kan dreje endnu en tak på afgift- og skatteskruen - og nogle gange praktiserer noget, der ligner planøkonomi.

Men danske løsninger kan som oftest tilpasses lokale forhold, og det fandt New Yorks miljømyndigheder heldigvis også ud af, da de skulle vælge rådgiver i forbindelse med et pilotprojekt i USA's største by.

Et ekspertteam fra Rambøll er i disse måneder i fuld gang med at dykke ned i kanaler og andre vandveje i New York-bydelen Queens for at forebygge konsekvenser af de voldsommere skybrud, der følger med klimaændringerne.

Ud over at nærstudere vandstrømmenes veje og vildveje skal Rambøll også beregne de positive effekter af forskellige former for klimatilpasning for de 400.000 indbyggere i dette område af Queens. Hvad betyder det for befolknin- gens sundhed, trivsel og livskvalitet, hvis man bruger kanaler, lommeparker og anden blågrøn infrastruktur til at lede vandet bort fra kældre og forretninger? Og i hvor høj grad understøtter Rambølls vandløsninger også en styrket social lighed og mangfoldighed i området?

New Yorks miljømyndigheder har fortalt os, at det netop er kombinationen af ekspertise på det vandtekniske og det økonomiske - og cost-benefit-analyser, der inddrager både miljømæssige, sociale og økonomiske konsekvenser - der er baggrunden for, at byens miljømyndigheder valgte os som rådgiver på projektet.

Et projekt, hvis resultater skal bruges i andre dele af New York.

\section{Holistiske FN-mål}

Nogle steder i verden nytter det dog ikke så meget at tale om livskvalitet og landskabsarkitektur. Ja, faktisk nytter det ofte heller ikke så meget at tale om Paris-aftalen og klimaproblemerne. Der er det stadig fattigdom og mere jordnære problemer, man må slås med. Og det er her, at FN's bæredygtighedsmål for alvor kommer ind i billedet. For de sigter i højere grad end Paris-aftalen mod bæredygtighed i bredere forstand.

Det fremgår af målene, at alle skal løftes ud af fattigdom, og at fremme af vedvarende energi i det globale energimix ikke må ske på bekostning af den øvrige udvikling i den fattige del af verden: Mål 7 fastslår, at fremtidens energi ikke kun skal være bæredygtig, men også moderne og pålidelig - og til at betale. Mål 6 taler om adgang til vand og sanitet for alle, 
og mål 9 om, at der skal bygges robust infrastruktur, promoveres bæredygtig industrialisering og skabes innovation.

Det rammer i høj grad også plet i ingeniørkoncerner, der som Rambøll har bygninger og transport som spidskompetencer, og som generelt har sat teknisk ekspertise i højsædet.

Man kan sige, at FN-målene er mere pragmatiske og holistiske end Paris-aftalen - og efter alt at dømme tættere på virkeligheden i mange af de regeringer og bystyrer, der skal udstikke kursen i de kommende år.

FN-landene har forpligtet sig til at bruge 0,7 procent af deres BNP på at nå målene - og både de rige og de fattige lande skal sørge for at gøre det mere attraktivt for virksomheder, pensionskasser og fonde at investere i at løse udfordringer med drikkevand, affald eller klima. Det er også derfor, at Global Green Growth Forum (3GF) i København tidligere i år fastslog, at bæredygtighedsmålene - ud over naturligvis at være med til at skabe en bedre og mere retfærdig verden - også er en 'billion-dollar-forretning. (1.000.000.000.000 dollar, red.). Det gælder ikke mindst for virksomheder som os, hvis værdier i årtier er blevet opbygget og udviklet ud fra et etisk samfunds- og menneskesyn, der ligger meget tæt op ad målene.

\section{Vigtigt lokalkendskab}

Rambøll og andre danske virksomheder har også en særlig fordel i forhold til FN's mål, fordi skiftende danske regeringer har været gode til at skabe en samlet tilgang til at løse de her miljømæssige, sociale og $ø$ konomiske udfordringer og selv imple- menteret dem i vores samfund. Ingen andre lande kan på samme måde præsentere en konkret og holistisk løsning på de massive problemer med bæredygtigheden, der især findes i alverdens byer.

Danmark er en socialøkonomisk helhed, som har arbejdet på denne dagsorden længe, så vi har lært, hvordan man gør det. Vi har lært af vores tekniske fejl. Og vi har lært, at den offentlige administration ofte fokuserer på deres egne fagområder - tænker i siloer - og at det kræver en jætteindsats at forbinde de forskellige fagområder og forskellige lag af byen; at forbinde kloaksystemer med transportnet, parker og bygninger, at arbejde på tværs af forskellige discipliner og sektorer - for kun sådan kan man lave en helhedsorienteret løsning.

Den viden og erfaring er andre nationer og byer interesserede $i$.

Men vi skal stadig være meget opmærksomme på, at løsningerne ikke bliver opfattet som alt for globale, og at vi både skal slå på 'Global Knowledge' og 'Local Presence'.

Når vi for eksempel tilbyder vandrensning og andre vandservices i Tyskland, er der tradition for, at små udbydere klarer den del af forsyningen - og så er vores lokale tilstedeværelse meget vigtig.

Det samme gælder i endnu højere grad i et land som Kina. Det lykkedes os i foråret at tage et meget stort skridt ind på dette verdens største marked for vindmøller ved at få en kontrakt på mere end 30 millioner kroner, hvor vi som den første ikke-kinesiske rådgiver skal designe en havvindmøllepark på 100 møller med en samlet kapacitet på 400 megawatt - cirka 350.000 danske hjems elforbrug.

Men vi skal stadig være meget opmærksomme på, at løsningerne ikke bliver opfattet som alt for globale, og at vi både skal slå på 'Global Knowledge' og 'Local Presence'. 
En stor del af forklaringen er de store danske erfaringer med vindmøller og Rambølls specialekspertise inden for havmøllefundamenter, hvor vi står bag næsten to tredjedele af samtlige i verden - for parken skal etableres 22 kilometer fra kysten i Jiangsu provinsen i et område, der er præget af jordskælv og meget bløde havbundsforhold.

Men Danmark som 'vindshowcase' og vores tekniske ekspertise ville ikke have været tilstrækkelig, hvis vi ikke havde haft medarbejdere med en dyb forståelse for det kinesiske sprog, forretningskultur og politiske landskab.

\section{Vigtigt med referencer hjemme}

Også i USA skal man have fingerspidsfornemmelse for sprog, kultur og politik. Det nytter for eksempel ikke noget at begynde at tale om, at myndighederne bør stille krav om vandbesparelser for at begrænse overforbruget - eller at staten bare kan lægge fjernvarmerør i vejene, så energisystemet kan effektiviseres. Begge dele er politisk betændt.

Her bliver vi nødt til henholdsvis at nøjes med $\mathrm{fx}$ at fremhæve vores erfaringer med 3D-undersøgelser af, hvor det er mest omkostningseffektivt at hente overfladevand - og starte med at tilbyde fjernvarme til universiteter eller andre steder, hvor store arealer har den samme ejer, og man derfor kan lave et integreret, effektivt mini-energisystem.

Det er lykkedes med MIT (Massachusetts Institute of Technology), der ligesom et andet amerikansk Ivy League-universitet, Dartmouth i New Hampshire, har valgt Rambøll som rådgiver i forsøget på at konvertere deres gamle dampvarmesystem til et mere moderne europæisk fjernvarmesystem.

En anden mulighed for at sælge district energy-systemer er at fokusere på fjernkøling, der ikke nødvendigvis kræver så store anlæg. Her har vi en rigtig god reference i den saudiarabiske by Makkah, hvor vi rådgiver om et af verdens største anlæg. Men vi mangler referencer i storskala herhjemme, fordi der er politiske barrierer - på trods af, at fjernkøling ifølge flere rapporter kan skabe rigtig mange job, bedre konkurrenceevne og øget eksport. Denne politiske barriere bliver derved til en eksportbarriere.

\section{Omstilling må ske gradvist}

Som tidligere nævnt kan det dog også være en barriere, hvis danske virksomheder for ensidigt henviser til eksempler fra hjemmemarkedet. For så er det, at kunderne måske tænker, at systemet er lavet til Danmark og vanskeligt kan overføres.

Så man skal balancere mellem at slå på, at danske virksomheders styrke er at kunne tilbyde systemløsninger - og så på den anden side understrege, at man kan tage enkeltelementer og tilpasse dem til kundens forhold. Hvis kunderne af politiske, praktiske eller andre grunde (endnu) ikke er interesserede i de store systemer - for eksempel fjernvarmeanlæg eller den helt store sammentænkning af energisystemet - må man starte i det små.

Her er det heldigvis en fordel, at et effektivt smart energisystem ikke behøver at indeholde alle disse mange komponenter. Et fuldt udbygget smart energisystem omfatter principielt alle led $\mathrm{i}$ forsyningskæden (fra produktion via distribution og lagring til forbrug af vedvarende energi), alle dele af slutforbruget (el, varme, køling, transport, proces) samt alle typer af vedvarende energiressourcer (vind, sol, biomasse, biogas, affald, vand, spildevand, overskudsvar- 
me). Men det skal ikke konstrueres på én gang, men kan og bør udbygges gradvist $i$ takt med en stigende andel fluktuerende energi.

Selve sprogbrugen skal heller ikke være for dansk. Hvis man for eksempel snakker om grøn transition, kan nogle beslutningstagere blive utilpasse, for hvor grøn skal en transition være, før den lever op til det udtryk, og er der nu råd til det?

Nogle steder er der måske råd til det, set med de langsigtede briller, men hvis man nu ikke føler, at man har råd til at have de briller på?

Flere organisationer mener for eksempel, at værtslandet for årets FN-klimakonference, Marokko, bør skrue mere op for investeringerne i solenergi. Og det kan også virke oplagt, da landet jo har en stor del af Sahara til sin rådighed. Men myndighederne føler selv, at det er for stor en mundfuld at gå direkte fra at være afhængig af olieimport til vedvarende energi. Derfor satser landet også i et vist omfang på naturgas - blandt andet med argumentet, at det vil højne forsyningssikkerheden og nedsætte $\mathrm{CO}_{2}$-udledningen i og med, at gas forurener mindre end olie og især kul.

Rambøll er enig og derfor medspiller i Marokkos såkaldte Gas-to-power-projekt, der skal dække en stor del af det stigende elektricitetsbehov de kommende år.

\section{Projekter i flere lande}

Marokkos gasprojekt er et eksempel på, at også udviklingslande kan afkoble forurening fra vækst, og det har Rambøll også erfaring med på mange andre områder.

Det kan vi blandt andet bruge i Indien, der har den højeste vækstrate blandt G20-landene, og som om et par år vil overhale Kina som det mest folkerige land i verden.
Strømmen af mennesker, der flytter fra landdistrikter til urbane områder, sætter infrastrukturen under voldsomt pres. Den indiske regerings plan er derfor at skabe 100 såkaldte Smart Cities med samlede investeringer på næsten seks milliarder dollars. Målet er at fremme bæredygtig byvækst, og Rambøll har taget de første skridt til at spille en central rolle i initiativet med en pilotundersøgelse i den historiske by Udaipur i Rajasthan.

Pilotundersøgelsen er lavet for at få en forståelse af udfordringerne og undersøge, hvordan international erfaring fra $\mathrm{fx}$ Norden og Singapore kan gavne indiske byer. Især en forståelse for om de teknikker, som Rambøll og andre har brugt til at afkoble forurening fra vækst, kan overføres.

Erfaringerne fra vores arbejde i 35 lande over hele kloden indikerer som allerede antydet, at det kan de.

Opfattelsen er mange steder, at verden er utrolig forskelligartet, men når det gælder bæredygtighed, er de basale udfordringer ofte forbavsende ens. $\mathrm{Da}$ Rambøll for et par år siden lavede en cost-benefit-analyse af prisen for ikke at skride ind over for øget vand- og luftforurening og andre miljøproblemer i den saudiarabiske by Jeddah, var konklusionen, at det ville koste to til fire pct. af storbyens BNP; én til to milliarder euro årligt. Rambøll blev derfor en af hovedrådgiverne på Jeddahs miljømæssige og sociale masterplan for de næsten fire millioner indbyggere, og vi henviser nu også til dette arbejde, når vi forhandler med bl.a. vores indiske kunder.

På samme måde henviser vi ikke kun til Copenhill - Bjarke Ingels innovative skibakkeformede fabrik på Amager i København, når vi taler om affaldsforbrænding. 
5

Det kan være en fordel at være dansk, fordi Danmark af historiske grunde har udviklet sig til at være en showcase på rigtig mange områder inden for bæredygtighed. Men det er meget væsentligt, at man ikke sælger løsningerne som danske

Referenceprojekter i hjemlandet er som nævnt meget vigtige - især når vi som her er verdensførende, hvad angår energieffektivitet på affaldsforbrænding. Men det er ikke altid nok, og derfor henviser vi også til andre projekter, bl.a. at vi hjælper med at få affaldet væk fra gaderne $\mathrm{i}$ Libanons hårdt prøvede hovedstad Beirut, der skal bygge en fabrik med kapacitet til 600.000 ton om året. Og til et projekt i Singapore, hvor vi er med til at designe verdens største integrerede anlæg for omdannelse af affald og spildevand til energi.

\section{Universelle teknikker}

Lad mig opsummere kort her til sidst:

Det kan være en fordel at være dansk, fordi Danmark af historiske grunde har udviklet sig til at være en showcase på rigtig mange områder inden for bæredygtighed. Men det er meget væsentligt, at man ikke sælger løsningerne som danske - og også på andre måder prøver at sikre, at kunderne ikke opfatter dem som skræddersyet til Danmark eller nabolandene.

For mange eksportkunder kan det måske synes for dyrt eller besværligt at overføre løsninger på grund af forskelle i for eksempel kultur, politik og økonomi. Her er det vores og andre danske virksomheders opgave at kommunikere, at bæredygtige energisystemer, klimasikring eller byudvikling kan bygges op gradvist, at vi både har globalt udsyn og lokalkendskab, og at vores teknikker er så universelle, at de kan tilpasses og bruges overalt på kloden. 

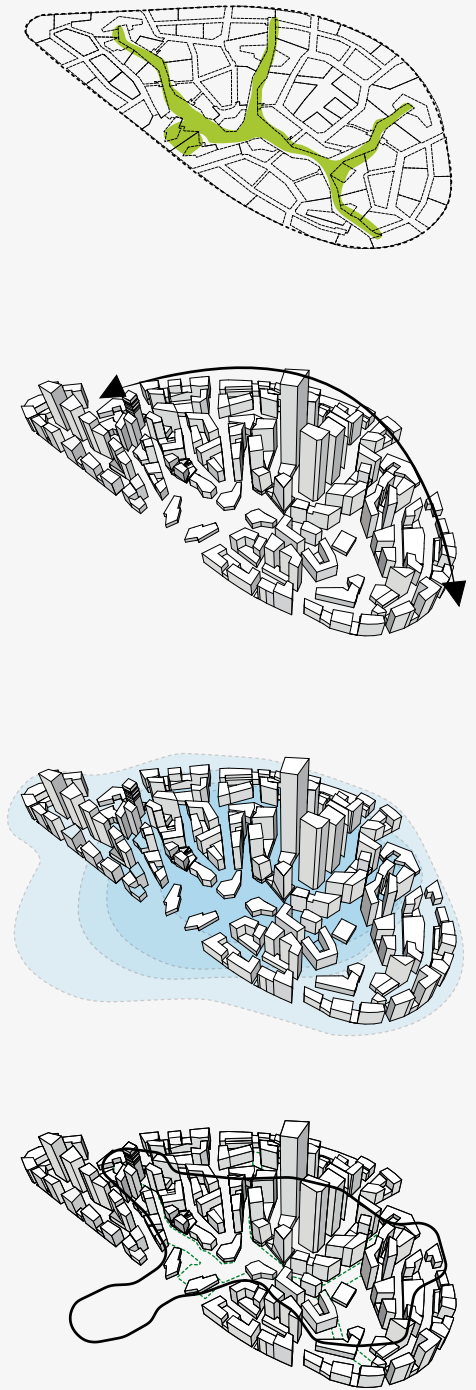

\section{Arealanvendelse}

Riyadh ligger i den saudiske ørken, hvor det er sà varmt, at indbyggerne foretrækker at køre i bil i stedet for at færdes til fods. Masterplanen tager derfor udgangspunkt $\mathrm{i}$ et eksisterende vådomráde, hvis kølige mikroklima udnyttes til rekreative arealer og gangzoner.

\section{Mikroklima}

Byens struktur planlægges med udgangspunkt i det grønne vådområde og formes $i$ en profil, som er højest mod midten og lavest langs kanten. På den måde ledes varme vinde og deraf afledte sandstorme hen over og uden om byen. Det gør byen rar at færdes i og mindsker skader på bydelens bygninger og infrastruktur.

\section{Fortætning}

Byen er tættest omkring centrum og mindre tæt langs periferien. Den tætte struktur giver masser af skygge og skaber et behageligt mikroklima. Bygningernes geometri sikres ved specifikke retningslinjer for designet på hver enkelt matrikel.

\section{Infrastruktur}

Fortætningen omkring centrum reducerer behovet for biltransport. Saudi-Arabiens første letbane og omkring 100 overdækkede skywalks sikrer en effektiv infrastruktur og reducerer bydelens samlede $\mathrm{CO}_{2}$-forbrug. 